\title{
Making Mural Painting With Collaboration of Students and Labschool Elementary School Students in Universitas Pendidikan Indonesia
}

\author{
Taswadi*, Heri Santosa \\ Departemen Pendidikan Seni Rupa \\ Universitas Pendidikan Indonesia \\ Bandung, Indonesia \\ *taswadi@upi.edu
}

\begin{abstract}
It is an obligation as an educational community in Higher Education to carry out community service in need. We are a team of lecturers who have expertise in drawing models, shapes, illustrations, guiding students and students of Labschool Elementary School to collaborate on drawing murals, because the school environment does not yet have mural drawings. In contrast to the junior high school next to it that looks more beautiful. This dedication was carried out by collaborative workshops between students and students, to draw murals on the walls of Labschool Elementary School. The purpose of this service is to beautify school buildings and increase awareness of the importance of cleanliness and beauty of the environment. The benefit of this service is to train the sensitivity of students and students to care about the beauty of the environment.
\end{abstract}

Keywords-collaboration, drawing murals, beautify the environment

\section{INTRODUCTION}

Schools are cultural formers [1]. Therefore it is important to provide the ability to play a role in developing a culture that grows in society. In the real development of culture, one of them is students able to work and work together with the community. The form of cooperation can be in the form of collaboration [2]. Forms of assistance between schools and communities are often carried out by previous educators. Among them [3], implementing collaborative learning with students in the field of sports, which results in increased student confidence. Other educators carry out the practice of student collaboration with the community [4] which produces a description of the competencies students must have in the 21 st century. The writer as a lecturer collaborates with the Indonesian Labschol Elementary School, which takes the form of a collaborative waorkshop to make murals on the walls. The difference in collaboration carried out in the lectures of writers with previous educators is, if the previous educators worked together to increase the confidence and ability of student competence in facing the 21st century. Other researchers [5] produce learning that can activate students. In contrast to what researchers do that produces more comprehensive competencies, both increasing self-confidence, being able to face the 21 st century, activating students, and producing real work, which can beautify the environment. The strengths of the results of collaboration that the authors do compared to previous researchers that can accompany students to train students to create art for the school environment. The impact can improve skills, instill a sense of beauty, strengthen cooperation. These results have not been produced by previous researchers.

\section{A. Collaboration on Making Mural Painting}

Collaboration or collaboration with in the study of mural painting conducted by Labschool students and students of the Department of Fine Arts, Education University of Indonesia produces quality work. Suata latest forms of learning by collaborative work so that the transfer of abilities will be more effective. Mural painting is a method of drawing or painting on a medium of walls, walls or broad surfaces that are permanent [6]. In Indonesia, mural paintings are often found on building walls, playgrounds, hotels and restaurants. Currently many murral paintings are also found in several shopping centers and schools. The use of mural painting makes the garden or a place of learning children will create fun and dynamism [7]. In some developed countries murals have penetrated into the home, especially the room / room of their children. the impression created in a room with bold colors gives rise to a good psychological message for the development of creativity [8].

\section{B. Labschool Bumi Siliwangi Indonesia Campus}

Labschool Campus Bumi Siliwangi Indonesia is a part of the Indonesian Education University academic community which is aimed at innovative learning trials, because innovation is one of the key characteristics of education [9]. Because of that, the vision of Labschool that will be reached is to become the leading school laboratory model in learning innovation and as a reference for the quality of education in Indonesia. Because innovation is important in education [10] In an effort to reach its ideals, policies are formulated by the 
leadership to run in Labschool, namely: (1) Innovation of regulations at the top down, from the development team formed in the form of management guidelines; (2) Innovations in the pre-eminent school facilities and infrastructure master plan in the form of Labschool; (3) Innovation in the attitude and spirit of change with a new mindset to form agents of change of three Labschool teachers in a bottom up manner; (4) Innovations in concrete collaboration between lecturers and teachers improve learning in the classroom and outside the classroom in the form of a convergence strategy in Labschool; and (5) Innovation in the promotion of school extracurricular excellence in the fields of arts, sports and regional and national level knowledge. All that because innovation is important for schools [11]. Based on observations from the dedication of the Department of Fine Arts Education with the UPI Lab School in 2019, there appears to be a more beautiful change in the walls of the Junior High School buildings compared to the Elementary School buildings that have not been given a mural image. On the basis of the above interests, the authors deem it necessary to continue the Community Service Program in collaboration in learning mural painting conducted by Lab school students and students of the Department of Fine Arts, Education University of Indonesia. The implementation of this service as a continuation of the 2019 service, which has produced mural wall decorations in junior high schools, for 2020 will continue collaboration with elementary school students. The writer as a lecturer in fine arts learning courses and a team that is capable of teaching drawing illustrations and painting at the Department of Fine Arts feels compelled to test the aesthetically pleasing walls with the works of fine arts students and school laboratory students. As part of the academic community of Universitas Pendidikan Indonesia, the author will test the concept of structuring by involving students and students collaboratively in structuring the Labschool environment.

\section{School Management}

School management will determine the success of educational programs [12]. Implementation of the management of the Education Program for Non-formal Education and Human Resource Development, in 2018-2020 the management of Labschool will emphasize innovation in facilities and infrastructure with superior and innovative school standards. Both the classroom and outside the classroom facilities must be arranged aesthetically, so that it can arouse the enthusiasm of learning in the whole community in learning. One of the supporters of the arrangement, namely the existence of the corners of the walls drawn to encourage students to learn. With drawing and writing designs containing aesthetic innovation and adapted to student development, the arrangement of the school environment will be a comfortable and comfortable place for students.

\section{MethodS}

This study uses the method of expository action research, [13], which is the practice of direct action. The population and sample were students participating in the Drawing Learning Model Model of the Faculty of Art Education and Design, Universitas Pendidikan Indonesia, totaling 10 students, and 10 Labschool Elementary School students. The research instrument used observation sheets, the value of the work and interviews. Observation sheet to record the observations of student and student behavior while applying the workshop method in collaboration outside the classroom. What was observed was the attitude of activeness and discipline. Activity is observed from the behavior of students and students during the work process. Behavior is observed and recorded descriptively with sentences or words, as expressed by [14]. The assessment of the work was submitted to the surrounding community with interview techniques to 3 people who were considered to represent each community, namely one student representing the age of the children, one student representing the youth group, and one community member who was over 40 years old representing adult society. They were asked to respond to the walls of the school before and after the mural was painted. More beautiful before painting or after painting. The results of the interviews of the three representatives as data to consider the conclusions of activities that have been successful or not.

\section{RESULTS AND DISCUSSION}

\section{A. Description of the Process of Collaborative Mural Painting Workshop}

The team consisting of the chairman and members accompanied by 10 students was preparing materials and tools for making murals. After all, the team rushed to the location of the activity. At the location, a teacher and 10 Labschool students who had been chosen by the teacher were gathering. Their team immediately welcomed them enthusiastically, intimately and happily. This as a sign of the emergence of positive symptoms in the process of cooperation begins with a nuance of familiarity and joy. Then the team joins the team that is already on site led by the team leader to make preparations. First introduce themselves to each other, then the team leader explains the technique of implementing Workshop collaboration through stages. The first stage, dividing the team into 2 groups, each consisting of 10 people namely 5 people from the elements of students and 5 people from students. The second stage, assigns the two groups the task of working together with each group to make one mural painting on the wall provided. In the third stage, the two groups were accompanied by a team leader from the Department of Fine Arts education and from the school rushed to approach the wall of the cane to be painted. Before painting members of the student elements seemed to give direction and invite members of the student elements. There appears to be a learning process. There was a transfer of mural painting techniques to students. The atmosphere seemed very familiar and harmonious. Members of the student element train students how to hit the wall, how to make an oaut line of drawing objects, how to mix colors, and how to color a picture. During the process of making murals the researchers recorded 
behavioral events that appeared to be good behavior by students and students in the form of descriptions on the observation sheet provided.

\section{B. Observation Note on Workshop Collaboration Process}

During the workshop collaboration practice, the writer records the behavior of students and students in the observation sheet that the author provides. Based on the author's observations the results of the notes can be observed in table 1 below:

TABLE I. STUDENT ATTITUDES AND BEHAVIOR DURING WORKSHOP COLLABORATION

\begin{tabular}{|l|l|}
\hline \multicolumn{1}{|c|}{ Type of Activity } & \multicolumn{1}{|c|}{ Results of Student and Behavior Notes } \\
\hline First Stage; Preparation & $\begin{array}{l}\text { The students and students looked very } \\
\text { happy and enthusiastic. }\end{array}$ \\
\hline $\begin{array}{l}\text { Second Stage; Division } \\
\text { and Assignment of Groups }\end{array}$ & $\begin{array}{l}\text { They seem to get along quickly and look } \\
\text { happy }\end{array}$ \\
\hline $\begin{array}{l}\text { Third Phase of the } \\
\text { Practical Work Process }\end{array}$ & $\begin{array}{l}\text { Students were seen guiding and inviting } \\
\text { pairs of other group members both fellow } \\
\text { students and with students, especially } \\
\text { students at the initial stage seemed hesitant } \\
\text { and asked lots of questions, but over time } \\
\text { the students began to work at work. }\end{array}$ \\
\hline
\end{tabular}

Based on observations during the implementation of collaborative work creation of mural paintings on the walls of the Labschol Elementary School building, it can be explained as follows:

In the first stage when the event will begin with the briefing of student behavior and students look happy and enthusiastic. The initial activity was marked by the enthusiasm of the implementers as a good start to achieve work success [15]. This shows one of the positive impacts in collaboration and work which creates an atmosphere of enthusiasm and pleasure [16]. How to work in doing a job turned out to cause psychic workers become happy. Such cooperation is also a refresher media that can foster motivation in work.

In the second stage, it appears that students and students have begun to collaborate with one another. It also shows the fun between students and students in groups. They look familiar with each other. So collaboration can strengthen brotherhood [17]. One of the goals of this collaboration activity is to strengthen the brotherhood, so that one of the objectives of this activity is achieved.

In the third stage, it appears that students and students have exchanged experiences with each other, learning processes occur between group members. There is a transfer of experience and knowledge between group members. Peer learning process occurs between students and between students, and learning occurs between brothers and sisters. Such conditions foster an awareness that living together and working together is more enjoyable. Such habits of life in the nilennial century tended to be individualistic, the depletion of social feeling [18] would be important to hold. So that the values of cooperation and mutual cooperation can be maintained. Evidenced by collaboration activities can foster a spirit of cooperation and mutual cooperation. Through collaboration, a lot of learning can be utilized. Not only the transfer of knowledge and skills, but the behavior of each other helps each other develop.

\section{Discussion on the Results of Work Valuation}

After the work is completed, the team then evaluates by interviewing several people who are considered to represent the composition of the community around the school building. To give a response whether the school building that has been drawn is more beautiful or worse with a building that has not been drawn by a mural. The results of the assessment in the form of community responses to the Dasasar Labschool School building, can be read in table 2 below:

TABLE II. RESULTS OF INTERVIEWS WITH STUDENTS, STUDENTS AND THE COMMUNITY

\begin{tabular}{|c|c|c|}
\hline $\begin{array}{l}\text { Subjects Are } \\
\text { Interviewed }\end{array}$ & Types of Questions & Answer \\
\hline Student & $\begin{array}{l}\text { 1. Did you know the building } \\
\text { before it was given a drawing? } \\
\text { 2. Do you think it is more } \\
\text { beautiful before or after a mural? }\end{array}$ & $\begin{array}{l}\text { 1. Knowing } \\
\text { 2. More beautiful } \\
\text { after being drawn. }\end{array}$ \\
\hline $\begin{array}{l}\text { College } \\
\text { student }\end{array}$ & $\begin{array}{l}\text { 1. Did you know the building } \\
\text { before it was given a drawing? } \\
2 \text {. Do you think it is more } \\
\text { beautiful before or after a mural? }\end{array}$ & $\begin{array}{l}\text { 1. Knowing } \\
\text { 2. More beautiful } \\
\text { after being drawn. }\end{array}$ \\
\hline Local society & $\begin{array}{l}\text { 1. Did you know the building } \\
\text { before it was given a drawing? } \\
\text { 2. Do you think it is more } \\
\text { beautiful before or after a mural? }\end{array}$ & $\begin{array}{l}\text { 1. Knowing } \\
\text { 2. More beautiful } \\
\text { after being drawn. }\end{array}$ \\
\hline
\end{tabular}

Based on the results of interviews with representatives of a student, student, and general public, it turns out the answer is the same, namely they know the Labschool Elementary school building before being given a mural picture, and when asked more beautiful before or after being drawn a mural, they have the same answer that is more beautiful after being given a mural picture. Thus the collaborative workshops of making mural paintings have succeeded in changing the Labschool Elementary School building to become more beautiful. As pendapa [19]. That the success of an activity if there is a change towards a better, and more positive. Collaborative activities have changed the behavior of students and students whose origins are not friends to become friends, whose origins do not work together.

\section{CONCLUSION}

After completing the research it can be concluded that narrative learning is appropriate to accelerate the process of students in determining themes in drawing. Because with narrative learning students are led to remember their own experiences, so it is easy to pour in the form of images. Narrative learning can also make students work according to personal experiences that are different from the experiences of others, this causes various forms of experience to affect the 
diversity of images. The diversity of forms of this image as one of the varied images. The form of varied images as a characteristic of creative creators. So it can be concluded that the application of the application of narrative learning by using the Workshop method can increase student creativity. The level of awareness and concern in maintaining cleanliness, natural beauty, and declining mutual cooperation culture and discipline in work can be regained through activities that have functions for the public interest. The assistance activities paint trash cans as one of the activities that can increase awareness of attitudes to care about the cleanliness and beauty of the environment in public places.

After carrying out collaborative workshops, painting murals on the walls of the walls of the Lab School conducted by students and students, it was concluded that collaboration activities can be used as a means to strengthen the fabric of brotherhood, can motivate work, can exchange abilities, and can reduce boredom and media refusing.

\section{REFERENCES}

[1] Y. Garna, Peranan Pendidikan dalam Pembentukan Kebudaya innovatifan Nasional. Makalah disampaikan pada Konvensi Nasional Pendidikan Indonesia II di Medan, 2002.

[2] R. E. Slavin. Cooperative Learning (terjemahan). Bandung: Nusa Media, 2008

[3] A.Rohman, "Model Pembelajaran Inter-Teams Game Tournament untuk Pengembangan Kemampuan Kolaborasi Mahasiswa Calon Guru," Jurnal FIP. Pp. 1-10. 2013.

[4] E.Y. Wijaya, D.A.Sudjimat, A. Nyoto, "Tranformasi Pendidikan Abad 21 Sebagai Tuntutan Pengembangan Pendidikan Sumber Daya Manusia di Abad Global." Prosiding Seminar Nasional Pendidikan Matematika 2016 Universitas Kanjuruhan Malang. Vol.1. pp. 263-278. 2016.

[5] Faisal, A. R. Saleh, S. Saenab, and Adnan, "Penerapan Pembelajaran Kolaborasi Melalui Kegiatan Lesson Study untuk Meningkatkan Aktivitas Belajar mahasiswa pada Mata Kuliah Inovasi Pembelajaran Biologi.” Jurnal Bionature, Vol.14, No.2. pp 88-94. 2013.

[6] M. Lutfi, Sejarah Seni Lukis-Lukisan Dinding (Mural). HUMANIORA. [Online] https://www.kompasiana.com/fianca97/54f79dcaa33311c6198b4595/sej arah-seni-lukislukisan-dinding-mural. 2014.

[7] Nonaka and Takeuchi, The Dynamics of Knowledge Creation, The Knowledge Advantage. NH: Capstone US, 1995.

[8] R. Satriatahun, Inspirasi Desain Mural Keren untuk Menghias Dinding Rumah Minimalis Anda. [Online] Available at: https://www.arsitag.com/article/inspirasi-desain-mural-keren-untukmenghias-dinding-rumah-minimalis-anda. 2016.

[9] P. Sammons, J. Hillman, and P. Mortimore, Key Characteristics of Effective Schools: A review of school effectiveness research A report by the Institute of Education for the Office for Standards in Education, 1995.

[10] D. Kaplan and A. Albert. Manners, Teori Budaya innovatif (Terjemahan B. Indonesia). Yogyakarta: Pustaka Pelajar, 2002

[11] J. Starey, Teori Budaya innovatif dan Budaya innovatif Pop (Terjemahan B. Indonesia). Yogyakarta: Qalam, 2003.

[12] S. Sudjana, H. Djudju, Manajemen Program Pendidikan untuk Pendidikan non formal dan Pengembangan Sumber Daya Manusia. Bandung: Falah Production, 2000.

[13] H. Kathryn, L. Gary, Anderson, The Action Research Dissertation: A Guide for Students and Faculty. Sage Publication, 2005.

[14] C. B. Robert and S. B. Knopp, Qualitative Research in Education: An Introduction to Theory and Methods.Boston: Allyn and Bacon, Inc., 1998.

[15] A.S. Kurniawan, P. Prastowo, Darussalim, L.P. Harahap, “Antusiasme Belajar Siswa Kelas X Ilmu Pengetahuan Bahasa pada Lintas Minat Biologi di MAN 2 Model Medan," Jurnal Pelita Pendidikan.Vol. 5, No. 1. Pp. $108-117$. n.d.

[16] A. Emda, "Kedudukan Motivasi Belajar Siswa dalam Pembelajaran." Lantanida Jurnal. Vol. 5 No. 2. Pp. 93-196. 2017.

[17] S. T. Dewi and W. M. Minza. "Strategi Mempertahankan Hubungan Pertemanan Lawan Jenis pada Dewasa Muda." Gajah Mada Journal of Psychology. Vol. 2, No. 3. Pp. 192-205. 2016

[18] H. A. Michener and D. D. John. Social Psychology. Orlando: Earl McPeek, 1999.

[19] V. Rahmayanti, "Pengaruh Minat Belajar Siswa Persepsi atas Upaya Guru dalam Memotivasi Belajar Siswa terhadap Prestasi Belajar Bahasa Indonesia Siswa SMP di Depok.," Jurnal SAP Vol. 1, No. 2. Pp. 206. 2016. 